\title{
PESANTREN DALAM BINGKAI POLITIK BIROKRASI PENDIDIKAN ISLAM DI INDONESIA
}

\author{
Ahmad Ali Riyadi ${ }^{*}$
}

\begin{abstract}
Abstrak
Gesekan politik dan pesantren sudah terjadi pada masa kolonial. Lembaga ini berperan menentang penetrasi kolonialisme yang pada akhirnya melakukan strategi uzlah atau menutup dan menghindar dari persoalan-persoalan politik. Peran seperti ini berlanjut sampai pada masa kemerdekaan. Sebagai dampaknya pesantren menjadi terisolisir dari persoalan-persolan politik dan kurang diperhitungkan eksistensinya secara nasional. Selanjutnya, terjadi perubahan orientasi politik di dunia pesantren, ketika intervensi politik menjangkau segenap jalur kehidupan sosial masyarakat, dengan adanya rekayasa penataan politik yang dikembangkan penguasa yang mempunyai dampak politis yang tidak dapat dihindari oleh lembaga pendidikan pesantren. Secara hegemonik, negara menguasai lembaga politik dan sosial kemasyarakatan dalam rangka menarik massa agar berada dalam spektrum kebijakan dan kekuasaan pemerintah. Dari sinilah pesantren yang semula independen dari atmosfir politik menjadi termobilisasi demi kepentingan penguasa.
\end{abstract}

Kata kunci; pesantren, politik birokrasi dan pendidikan

\section{Pendahuluan}

Proses perubahan sosio-kultural yang berlangsung dalam iklim pembangunan di Indonesia telah menjamah setiap sudut kehidupan. Pesantren, sebagai salah satu subkultur sosial yang seringkali disebut orang sebagai lembaga tradisional yang ada di

\footnotetext{
* Universitas Darul Ulul Jombang
} 
Indonesia, tidak luput dari jangkauan proses tersebut. Eksistensinya akan selalu ditantang oleh perubahan sebagai sebuah kebutuhan yang mengalami pergeseran nilai. Kemampuan pesantren memenuhi tuntutan kebutuhan pendukungnya menjadi batu ujian bagi kelangsungan eksistensinya sehingga transformasi sosio-kultural yang ditempuhnya harus senantiasa memperhatikan perubahan yang terjadi dalam lingkungannya.

Pada prinsipnya, pesantren sebagai salah satu lembaga pendidikan Islam di Indonesia tertua, merupakan pusat kegiatan keagamaan murni (tafaqquh fiddin) untuk penyiaran agama Islam. Itulah identitas pesantren pada awal perkembangannya. Identitas lain yang sering melekat pada pesantren adalah sebagai lembaga pendidikan Islam tradisional yang mengajarkan Islam ortodoks secara konservatif. Kini, sebutan-sebutan yang mengesankan jauh dari modernitas tidak lagi memadai, walaupun pesantren tetap mempertahankan ciri khas sebagai lembaga pendidikan agama, sesuai dengan kemajuan zamannya. Pesantren tetap eksis dan mampu melakukan evolusi mengikuti perkembangan dan perubahan. Boleh dikata, pesantren telah mampu mengalami inovasi-inovasi secara interen maupun eksternal untuk merespon perubahan. Tulisan berikut mencoba memotret respon pesantren terhadap kekuatan-kekuatan eksternal. Ada dua persoalan yang disoroti tulisan ini. Pertama, menyangkut kebijakan politik pemerintah yang telah memaksa pesantren untuk mengikuti pola-pola kebijakan yang telah ditentukan demi pembangunan. Pada sisi yang lainnya, menyangkut keterlibatan pesantren sebagai suatu lembaga "tradisional" untuk terlibat dalam kegiatan pengembangan masyarakat.

\section{Pesantren dalam Bingkai Politik}

Gesekan politik dan pesantren sudah terjadi pada masa kolonial. Lembaga ini berperan menentang penetrasi kolonialisme yang pada akhirnya melakukan strategi uzlah atau menutup dan menghindar dari persoalan-persoalan politik. Peran seperti ini berlanjut sampai pada masa kemerdekaan. Sebagai dampaknya pesantren menjadi terisolisir dari persoalan-persolan politik dan kurang diperhitungkan eksistensinya secara nasional. 
Selanjutnya, terjadi perubahan orientasi politik di dunia pesantren, ketika intervensi politik menjangkau segenap jalur kehidupan sosial masyarakat, dengan adanya rekayasa penataan politik yang dikembangkan penguasa yang mempunyai dampak politis yang tidak dapat dihindari oleh lembaga pendidikan pesantren. Secara hegemonik, negara menguasai lembaga politik dan sosial kemasyarakatan dalam rangka menarik massa agar berada dalam spektrum kebijakan dan kekuasaan pemerintah. Dari sinilah pesantren yang semula independen dari atmosfir politik menjadi termobilisasi demi kepentingan penguasa. Mobilisasi di sini dipahami sebagai pengakomodasian kepentingan pesantren demi mendukung sepenuhnya rekayasa pembangunan pemerintah.

Dalam konteks pembahasan ini, ada beberapa persoalan penting yang perlu diperhatikan untuk memahami keterlibatan pesantren dalam atmosfir politik. Pertama, pelembagaan ulama lewat pesantren. Kedua, kedudukan lembaga pesantren di tengah masyarakat. Persoalan yang pertama mengarah kepada kedudukan ulama dalam pesantren sebagai basis institusi ulama. Hal ini didasarkan pada kenyataan bahwa di dalam bangunan pesantren ulama merupakan otoritas tunggal dan monopoli penafsiran keagamaan sekaligus sebagai penjelmaan dari paham keagamaan itu sendiri. ${ }^{1}$ Ulama dianggap sebagai penyalur kemurahan Tuhan kepada santri-santri dan masyarakat sekitarnya. Posisi ulama dilihat sebagai puncak karir seorang santri dan pesantren menjadi sarana proses mobilisasi sosial. Pada faktor kedua, didukung kenyataan bahwa kedudukan ulama selalu mendapat tempat terhormat di tengah masyarakat sekitar pesantren. Ulama mempunyai otoritas yang tinggi di tengah tempat tinggalnya. Sikap hidup yang dibangun ulama di pesantren mempengaruhi pola kehidupan sosial keagamaan masyarakat sekitar pesantren berada. ${ }^{2}$ Dalam kerangka inilah

${ }^{1}$ Jajat Burhanuddin, "Ulama dan Politik Pembentukan Umat: Sekilas Pengalaman Sejarah Indonesia," dalam Jajat Burhanuddin dan Ahmad Baedlowi, Transformasi Otoritas Keagamaan: Pengalaman Islam Indonesia (Jakarta; Gramedia, 2003), h. 22.

${ }^{2}$ Tentang h ini lihat Dawam Rahardjo, "Kyai dalam Perubahan Sosial," dalam Pesantren, No. 4/ Vol. II/1985, h. 20-29. 
ulama menjadi agen proses intensifikasi keislaman masyarakat.

Secara historis, pesantren selalu dikaitkan dengan organisasi Nahdlatul Ulama (NU). ${ }^{3}$ Argumen yang dapat mendukung pendapat ini didasarkan pada kenyataan bahwa pesantren selalu berafiliasi pada organisasi ini, meskipun ada juga pesantren yang tidak berafiliasi pada lembaga tersebut, bahkan netral terhadap ormas keagamaan dan kekuatan sosial politik tertentu. Dari 11.312 pondok pesantren (ponpes) yang ada, $7.306(64,59 \%)$ berafiliasi ke NU, 184 (1,63\%) ponpes berafiliasi ke Muhammadiyah, $49(0,43 \%)$ ponpes berafiliasi ke Persis, $118(1,04 \%)$ ponpes berafiliasi ke Al-Washliyah, 46 $(0,41 \%$ ponpes berafiliasi ke Persatuan Umat Islam (PUI), 33 $(0,29 \%)$ ponpes berafiliasi ke Mathla'ul Anwar, 50 (0,44\%) ponpes berafiliasi ke al-Khairat, $97(0,86 \%)$ ponpes berafiliasi ke Nahdlatul Wathan, $51(0,45 \%)$ ponpes berafiliasi ke Darud Dakwah wal Irshad, 137 (1,21\%) ponpes berafiliasi ke Perti, 43 $(0,38 \%)$ ponpes berafiliasi ke GUPPI, $10(0,09 \%)$ ponpes berafiliasi ke LDII, dan sebanyak $572(5,06 \%)$ ponpes berafiliasi ke ormas lainnya. Sebanyak $2.616(23,13 \%)$ ponpes menyatakan mandiri. ${ }^{4}$ Data ini menunjukkan banyaknya pesantren yang berafiliasi pada NU, sehingga dapat dikatakan untuk mengkaji peran politik pesantren dengan politik sangat berhubungan dengan dinamika perpolitikan NU vis a vis pemerintah.

Hubungan politik dengan pesantren dapat dicermati mulai masa awal kemerdekaan (Orde Lama) dan berlanjut masa Orde Baru dan berlanjut pada masa Reformasi. Perseteruan sengit terjadi di tahun 70-an, ketika pemilihan umum pertama kali diadakan pada masa Orde Baru di tahun 1971, afiliasi politik elit pesantren (kyai) dapat diidentifikasi. Hal ini dapat dilihat dari besarnya dukungan para kyai dan pesantren pada Partai NU, di samping dukungan para kyai dan pesantrennya pada partai-partai Islam yang lain seperti PARMUSI dan PSII. Tampaknya dukungan yang diberikan para petinggi NU pada

${ }^{3}$ Sudirman Tebba, "Dilema Pesantren: Belenggu Politik dan Pembaruan Sosial," dalam Dawam Rahardjo (edt.), Pergulatan Dunia Pesantren: Membangun Dari Bawah (Jakarta; P3M, 1985), h. 277.

${ }^{4}$ Depag RI, Pondok Pesantren (Jakarta; Depag, 2001), h. 28. 
waktu itu masih sebatas pada partai yang bergariskan Islam. ${ }^{5}$

Fernomena itu berubah di tahun 1973 pada saat Orde Baru melakukan penyederhanaan partai-partai melalui kebijakan fusi, yang memasukkan partai-partai Islam ke dalam Partai Persatuan Pembangunan (PPP). Afiliasi politik kyai mulai pudar tidak hanya pada PPP saja, akan tetapi banyak kyai yang mendukung partai selain partai PPP, yakni Golkar dan PDI. Beberapa kyai kedapatan secara terbuka mendukung Golkar misalkan, di Jawa Timur, KH. Musta'in Romly (PP Darul Ulum Jombang), KH. Karim Hasyim (putra Kyai Hasjim Asy'ari dari PP Tebuireng Jombang), KH. Badrus Saleh dari Kediri, Kyai Zaini dari Probolinggo, dan sebagainya. Bahkan, ada beberapa kyai setelah pesantrennya mendapatkan bantuan dana dari pemerintah kemudian mendukung Golkar, seperti PP al-Kamal Blitar, PP Sabilul Muttaqin Takeran, dan PP Nahdlatul Wathon Lombok Timur. ${ }^{6}$

Begitu juga di tahun 1985 ketika Orde Baru menerapkan asas tunggal Pancasila bagi segenap Ormas dan Orsospol dengan dikeluarkannya UU No. 3 tahun 1985 tentang Asas Tunggal dan Partai Politik. Hal ini menambah pudarnya afiliasi kyai dan pesantren pada PPP saja, yang dianggap sebagai partai berasas Islam. Pada Pemilu 1992, banyak pondok pesantren yang memberikan dukungan kepada PPP, ada yang bergabung dalam Golkar, ada yang bergabung ke PDI, ada pondok pesantren yang netral dalam artian tidak mendukung ketiga partai yang ada, bahkan golput (golongan putih). Kyai yang mendukung PPP adalah Kyai Syamsuri Badawi dari PP. Tebuireng Jombang, KH. Maksum dari PP. Lirboyo Kediri, KH. Nizar Nawawi dari PP Raudlatul Muta'allimin Pasuruan, KH. Zaki Gufron Wakil Ketua NU Jatim, KH. Hasib Wahab PP Bahrul Ulum, KH. Arifin PP Denanyar Jombang, KH. Ilyar Ruchiyat PP. Cipasung Jabar, KH. Nadzir Muhammad dari PP. Asyidiqiyah Jember. Sementara yang ikut bergabung dalam Golkar diantaranya KH. Muhammad As'ad Umar dan KH. Rifai

${ }^{5}$ Muhammad Asfar,"Pergeseran Otoritas Kepemimpinan Politik Kiai," dalam Prisma 5, Mei 1995, h. 31

${ }^{6}$ Ibid. h. 32. 
Romli dari PP Tebuireng Jombang dan KH. Seichul Hadi Purnomo. Diantara yang netral adalah KH. Yusuf Hasjim dari PP Tebuireng Jombang, KH. Shoib Bisri dari Mamba'ul Ma'arif Jombang, KH. Ali Wafa, KH. Husnan Mutawakil Ridwan. Diantara pendukung PDI adalah KH. Khatib dari Jember dan Tengku Syeh Haji Rajali dari Aceh. Diantara yang golput adalah KH. Darul Alfiah dari PP. Gentur Cianjur. ${ }^{7}$

Afiliasi politik kyai terhadap partai-partai tersebut bukannya tanpa gesekan, karena adanya perbedaan dalam menyikapi kebijakan politik. Gesekan ini bermula dari sikap NU ketika menolak fusi ke dalam PPP tahun 1973, begitu juga sikap keras menolak yang ditunjukkan sebagian wakil NU di DPR ketika pemerintah mengajukan RUU Perkawinan tahun 1973 dan walk out yang dilakukan unsur NU dalam Sidang Umum MPR 1978, mendorong pemerintah mengambil tindakan tegas terhadap NU. Sikap tegas pemerintah ditunjukkan dengan penyingkiran tokoh-tokoh NU di Departemen Agama dengan menempatkan Mukti Ali sebagai Menteri Agama dalam Kabinet Pembangunan II (1973-1978), juga menempatkan pejabatpejabat untuk menduduki posisi kunci di Departemen Agama semisal M. Kafrawi, Muljanto Sumardi dan Bahrun Rangkuti. ${ }^{8}$ Begitu juga banyak dari tokoh-tokoh NU yang mempunyai suara sumbang tidak diperbolehkan lagi menjadi anggota dewan setelah Pemilu 1982. ${ }^{9}$ Perdebatan seputar penerapan asas tunggal di kalangan NU, keluarnya NU dari Partai Persatuan Pembangunan dan pengunduran diri dari politik praktis juga menambah dinamika perjalanan politik NU yang diwakili

${ }^{7}$ Tempo, 21 September 1991 dan 30 Mei 1992; Surabaya Post, 20-29 Mei 1992. Sebagaimana dikutip Muhammad Asfar,"Pergeseran Otoritas..., , h. 32.

${ }^{8}$ Mereka yang menduduki posisi penting adalah para kader terbaik Muhammadiyah. Nampaknya, apa yang dilakukan pemerintah adalah untuk memanfaatkan perpecahan dan perseturuan antara Muhammadiyah dan Nahdlatul Ulama dengan cara mengadu domba diantara keduanya. Pada sisi yang lain, peristiwa tersebut adalah suatu keberhasilan Muhammadiyah dalam meraih kepercayaan di mata pemerintah Orde Baru.

${ }^{9}$ Sudirman Tebba,’Dilema Pesantren...," h. 286. 
kalangan elit pesantren. ${ }^{10}$

Langkah perpolitikan NU terhadap sikap represif pemerintah Orde Baru tersebut lebih mengarah kepada hubungan yang bersifat antagonistik. Antara keduanya selalu terjadi kecurigaan yang berlebihan. Pemerintah secara konsisten melaksanakan gagasan pembangunan ekonomi dengan pembangunan politik dan penyederhanaan partai-partai dalam rangka menciptakan stabilitas nasional untuk mendukung pembangunan ekonomi. Hal ini justru menimbulkan kecurigaan di kalangan agamawan (NU) bahwa pembangunan politik pemerintah Orde Baru lebih mengarah pada sekularisasi dengan membabat habis semua ciri khas keagamaan yang mengarah kepada kekuatan-kekuatan sosial politik.

Babak baru langkah politik NU terjadi ketika Abdurrahman Wahid (Gus Dur) memegang pucuk pimpinan. NU yang dimotori Gus Dur melakukan manuver politik dengan sikap yang lebih akomodatif terhadap politik pemerintah Orde Baru, yakni menerima Pancasila sebagai satu-satunya asas organisasi. Peristiwa ini ditunjukkan dengan pernyataan politik NU dalam muktamarnya ke 27 di Pesantren Salafiyah Syafi'iyah Situbondo, sekaligus statemen politik kembali ke Khitthah 1926 yang berarti meninggalkan politik praktis, termasuk bersikap ganda terhadap PPP sebagai induk perpolitikan yang berbasis keagamaan. ${ }^{11}$

Langkah politik NU tersebut membawa dampak lebih lanjut pada perkembangan pesantren, baik secara vertikal maupun horizontal. Secara horizontal, keputusan tersebut membawa dampak pada legitimasi politik bagi pesantren dalam mengantisipasi perubahan yang terjadi dengan menggalang kerjasama yang lebih luas terhadap lembaga-lembaga yang didirikan pemerintah, yang berdampak pada usaha pemerintah membantu pesantren berupa dana dan guru melalui Departemen

${ }^{10}$ Keterangan lebih jelas tentang persoalan tersebut lihat Andree Feillard, NU Vis-à-vis Negara: Pencarian Isi, Bentuk dan Makna, penerj. Lesmana (Yogyakarta; LKiS, 1999), 187-271.

${ }^{11}$ A. Gaffar Karim, Metamorfosis NU dan Politisasi Islam Indonesia (Yogyakarta; LKiS, 1995), h. 136. 
Agama. Begitu pula dengan tidak keluar dari PPP secara vertikal memberi kemungkinan bagi pesantren untuk tetap menjadi penyedia person politik untuk PPP dan kekuatan sosial politik di luarnya. ${ }^{12}$

Secara politis pedagogis, munculnya bantuan finansial yang diberikan pemerintah kepada pesantren menimbulkan persoalan secara politis maupun ekonomis terhadap pesantren. Secara politis berhubungan dengan kebijakan pembangunan politik Orde Baru yang bersifat represif terhadap pendidikan yang berciri khas keagamaan dari kehidupan politik. Hal ini membawa dampak pada ketidakmampuan pesantren ikut mewarnai kebijakan politik pendidikan yang digagas Orde Baru. begitu juga pendidikan yang berkembang di pesantren terjebak pada paradigma nasionalisasi, strukturisasi, formalisasi dan depolitisasi pendidikan, yang mengarah kepada peminggiran lembaga pendidikan pesantren. Pada sisi yang lain, dari segi ekonomi, menimbulkan sikap ketergantungan pesantren terhadap subsidi yang diberikan pemerintah. Posisi tergantung pesantren ini tidak mustahil dimanfaatkan oleh pemerintah lewat partai politik. Secara kasuistis di tahun 1985 partai Golongan Karya (Golkar) partai dukungan pemeritah menjadikan pesantren tempat pembinaan kader-kadernya. ${ }^{13}$ Namun demikian, adaptasi yang dilakukan pesantren terhadap kebijakan pemerintah tidak jarang membawa dampak positif bagi posisi tawar agar orang-orang pesantren memperoleh posisi penting dalam lembaga-lembaga legislatif maupun eksekutif di pemerintahan.

Fenomena politik tersebut tidak hanya berdampak pada eksistensi pesantren yang perlu diperhitungkan dalam atmosfir politik, tetapi juga berdampak pada sikap pesantren dalam mengantisipasi sistem pendidikan yang dianut pemerintah. Interaksi pesantren dengan pendidikan bermula dari rekayasa politik pemerintah untuk menata sistem pendidikannya dengan langkah modernisasi pendidikan mengikuti pola pendidikan modern Barat yang diperkenalkan oleh pemerintah kolonial

\footnotetext{
${ }^{12}$ Sudirman Tebba,"Dilema Pesantren...," h. 280.

${ }^{13}$ Ibid. h. 286.
} 
Belanda. ${ }^{14}$ Pada masa ini pesantren mengalami tantangan yang berat disebabkan ekspansi sistem pendidikan modern yang diikuti pemerintah. Bahkan, ditinjau dari segi politik pendidikan, pesantren dalam konteks sistem pendidikan nasional tidak mendapatkan pengakuan secara formal. Hal ini dapat dicermati dari kebijakan pemerintah yang memasukkan pesantren dalam pendidikan jalur luar sekolah sesuai dengan PP No. 73 tahun 1991 tentang Pendidikan Luar Sekolah. Secara eksplisit dalam bab III pasal 3 ayat (1) dikatakan bahwa jenis pendidikan luar sekolah terdiri atas pendidikan umum, keagamaan, pendidikan jabatan kerja, pendidikan kedinasan dan pendidikan kejuruan. ${ }^{15}$ Pondok pesantren termasuk dalam pendidikan yang bercorak keagamaan dan membawa konsekuensi pada out-put pondok pesantren tidak diakui keberadaannya secara formal.

Pemerintah menganggap proses belajar mengajar di pondok pesantren tidak memenuhi standar yang telah ditetapkan karena sistem pendidikan pondok pesantren lebih didominasi oleh muatan-muatan agama, menggunakan kurikulum yang belum standar, memiliki struktur yang tidak seragam, dan menggunakan manajemen yang tidak dapat dikontrol oleh pemerintah. $^{16}$ Tampaknya pemerintah menerapkan standar ganda. Satu sisi pesantren dianggap pemerintah sebagai lembaga yang harus dibina dan dikembangkan karena mempunyai peran yang cukup strategis untuk ikut memobolisasi masyarakat guna mendukung stabilnya pembangunan ekonomi, namun di sisi lain keberadaan pondok pesantren ditempatkan jauh dari sistem pendidikan nasional. Karena bagaimanpun juga sistem

${ }^{14}$ Azyumardi Azra,"Pesantren: Kontinuitas dan Perubahan," dalam Nurcholish Madjid, Bilik-Bilik Pesantren..., h. xii.

${ }^{15}$ Lebih lengkapnya lihat "Peraturan Pemerintah Republik Indonesia Nomor 73 tahun 1991 tentang Pendidikan Luar Sekolah", dalam Himpunan Peraturan Perundang-Undangan Tentang Pendidikan Nasional (Perguruan Agama Islam), (Depag RI; Ditjen Binbaga Islam, 1998), h. 442

${ }^{16} \mathrm{H}$ itu sebagai akibat pemerintah menganut sistem pendidikan Belanda yang dinilai lebih modern dan mempunyai sistem yang standar. Tentunya $h$ ini membawa dampak pada kemarjinalan posisi pesantren dalam sistem pendidikan nasional. 
pendidikan pondok pesantren dianggap tidak mempunyai standar yang baku.

Fenomena tersebut sangat menyulitkan kedudukan pesantren dalam percaturan sistem pendidikan Orde Baru, sehingga dalam konteks perkembangan kesejarahan, pesantren merespon kebijakan Orde Baru sesuai dengan dinamikanya, dalam artian ada pesantren yang merespon secara akomodatif dan ada juga pesantren yang merespon secara defensif. Ada pesantren yang meresponnya dengan merevisi kurikulumnya dan memasukkan semakin banyak mata pelajaran umum dan membuka kelembagaan serta fasilitas-fasilitas pendidikannya bagi kependidikan umum. Pada sisi yang lain, ada pesantren yang tetap melakukan peran bertahan dengan mempertahankan substansi pendidikan tradisional.

Pada persoalan pertama pesantren merespon kebijakan pendidikan Orde Baru dengan melakukan evolusi pendidikan dengan membuka lembaga pendidikan modern (umum), merupakan dinamika tersendiri setelah merasa tersaingi dengan sistem kelembagaan madrasah sebagai lembaga modern yang dikembangkan pemerintah. Untuk merespon perkembangan tersebut semakin banyak pesantren yang mendirikan pendidikan modern di dalam kompleks pesantren masing-masing. Dengan cara ini pesantren tetap berfungsi sebagai pesantren dalam pengertian aslinya, yaitu tempat pendidikan dan pengajaran bagi santri yang ingin memperoleh pengetahuan Islam secara mendalam dan sekaligus madrasah bagi anak-anak di lingkungan pesantren. Sebagian murid-murid madrasah ini sekaligus menjadi santri tetap di pesantren yang bersangkutan. ${ }^{17}$

${ }^{17}$ Berikut data yang menunjukkan santri tetap yang belajar di sekolah formal di dalam pondok pesantren; $26.548(1,84 \%)$ belajar di RA, 7,18\% di MI, 192.200 (13,49\% di MTs, 86.026 (5,95\%) belajar di MA, $9.868(0,68 \%)$ belajar di MAK, 2,498 (0,17\%) belajar di MA Keterampilan, dan $5.929(0,41 \%)$ belajar di PTAI. Semua data tersebut berada di bawah koordinasi Departemen Agama yang dikelola ponpes. Sedang lembaga pendidikan yang dikelola ponpes yang berada dalam Departemen Pendidikan dan Kebudayaan adalah ada $2.167(0,15 \%)$ santri menempuh pendidikan TK, $5.244 \quad(0,36 \%)$ menempuh pendidikan SD, $20.415(1,41 \%)$ menempuh SMP, $4,725 \%(0,33 \%)$ di 
Dengan mendaftar sebagai santri murid madrasah mereka kemudian mendapatkan pengakuan dari Departemen Agama dan memiliki akses lebih besar tidak hanya dalam melanjutkan pendidikan, akan tetapi juga dalam lapangan kerja. Dalam perkembangan selanjutnya tidak jarang ditemukan pesantren memiliki lebih banyak murid madrasah dari pada santri yang hanya belajar ngaji khusus di pesantren. ${ }^{18}$

Beberapa pesantren tidak hanya mengembangkan eksperimennya mendirikan lembaga-lembaga pendidikan bersistem madrasi. Beberapa pesantren bahkan mendirikan lembaga-lembaga pendidikan umum yang berada di bawah sistem Departemen Pendidikan dan Kebudayaan bukan yang lazim mengikuti pembinaan di bawah Departemen Agama. Dengan pengertian, pesantren bukan hanya mendirikan madrasah tetapi juga sekolah-sekolah umum yang mengikuti sistem dan kurikulum Departemen Pendidikan dan Kebudayaan. ${ }^{19}$ Ada juga sebagian madrasah di pesantren yang tidak bersedia

SMPT, $14.500(1,00 \%)$ di SMU, $3.694(0,26 \%$ di SMK dan 1.636 (0,11\%) di PTU. Depag, Pondok Pesantren ..., h. 29

${ }^{18}$ Sedangkan data santri tetap yang belajar di lembaga pendidikan yang ada di luar pondok pesantren; $14.362(0,99 \%)$ belajar di RA, 56.061 (3,88\%) belajar di MI, 63.332 (4,38\%) belajar di MTs, $2.794(0,19 \%)$ di MTsT, $31.933(2,21 \%)$ di MA, $3.460(0,24 \%)$ di MAK, $535(0,04 \%)$ belajar di MA dan $4.638(0,32 \%)$ di PTAI. Sedangkan santri yang belajar di lembaga umum sebagai berikut; $2.275(0,16 \%)$ di TK, $14.524(1,00 \%)$ di SD, $15.171(1,05 \%)$ di SMP, $3.985(0,28 \% 0$ di SMPT, $10.227(0,71 \%)$ di SMU, $4.007(0,28 \%)$ di SMK dan $1.665(0,12 \%)$ yang belajat di PTU. Ibid., h. 31.

${ }^{19}$ Beberapa pesantren banyak yang menyelenggarakan jenjang pendidikan umum. Dari 11.312 pesantren, 165 (1,46\%) ponpes menyelenggarakan Taman Kanak-Kanak, 144 (1,27\%) ponpes mendirikan Sekolah Dasar/SD, 301 (2,66\%) ponpes mendirikan Sekolah Menengah Atas/SMP, $118(1,04 \%)$ ponpes mendirikan Sekolah Menengah Terbuka/SMPT, $216(1,91 \%)$ ponpes mendirikan Sekolah Menengah Umum/SMU, $85(0,75 \%$ ponpes mendirikan Sekolah Menengah Kejuruan/SMK, $21(0,19 \%)$ ponpes mendirikan perguruan umum. Sedangkan ada juga ponpes yang mendirikan lembaga pendidikan yang berciri khas Islam. Data naratif menunjukkan sebanyak $95(0,84 \%)$ pesantren menyelenggarakan Perguruan Tinggi Agama Islam (PTAI), $23(0,20 \%)$ mengembangkan Madrasah Aliyah Ketrampilan, 135 (1,19\%) pesantren mengadakan Madrasah Aliyah Keagamaan (MAK), 1.305 (11,54\%) 
mengikuti dan menyesuaikan kurikulumnya dengan pola kurikulum pemerintah, tapi membuat kurikulum sendiri sesuai dengan idealisme pesantren yang bersangkutan. Hal itu dilakukan untuk merespon kebutuhan umat, khususnya berkenaan dengan kebutuhan masa depan santri untuk bisa mengakses pendidikan yang lebih tinggi.

Deskripsi di atas menunjukkan bagaimana respon pesantren dalam menghadapi berbagai perubahan di sekililingnya. Dalam menghadapi semua perubahan dan tantangan itu para eksponen pesantren tidak begitu saja melepaskan dan memfokuskan kelembagaan pesantren menjadi lembaga pendidikan modern Islam sepenuhnya, akan tetapi sebaliknya mereka cenderung mempertahankan kebijakan lembaganya secara hati-hati. Mereka menerima pembaharuan pendidikan hanya dalam skala yang terbatas mampu menjamin pesantren tetap eksis.

\section{Pesantren Dalam Bingkai Birokrasi Pendidikan}

Pemerintah lewat Departemen Agama juga melaksanakan pembinaan terhadap pondok pesantren. Berdasarkan ketentuan tentang jalur pendidikan, pondok pesantren, dalam arti satuan pendidikan yang menyelenggarakan pendidikan secara individual, tidak berjenjang dan berkesinambungan diletakkan pada jalur pendidikan luar sekolah. Pelaksanaan pendidikan jalur luar sekolah ini didasarkan pada PP No. 73 tahun 1991 tentang Pendidikan Luar Sekolah. Secara eksplisit dalam bab III pasal 3 ayat (1) jenis pendidikan luar sekolah terdiri atas pendidikan umum, pendidikan keagamaan, pendidikan jabatan kerja, pendidikan kedinasan dan pendidikan kejuruan. Dari penjelasan inilah pesantren sebagai pendidikan keagamaan eksistensinya diakui sebagai sebuah lembaga pendidikan non formal. Sebagai

Madrasah Aliyah, $93(0,82 \%)$ pesantren memiliki Madrasah Tsanawiyah Terbuka (MTsT), 2.256 (19,94\%) pesantren membuka Madrasah Tsanawiyah (Mts), 1.904 (16.83\%) pesantren membuka Madrasah Ibtidaiyah. Hampir data ini, menunjukkan bahwa lembaga pendidikan yang diselenggarakan pesantren berstatus swasta. Ibid., h. 29. 
realisasinya Departemen Agama kemudian mengeluarkan Kepmenag No. 225 tahun 1992 tanggal 01-10-1992 tentang pemberian bantuan untuk pembinaan pondok pesantren ${ }^{20}$ dan diteruskan dengan Keputusan Ditjen Binbaga Agama Islam No. 80/E/1992 tanggal 30-9-1992 yang memberikan bantuan kepada pondok pesantren. ${ }^{21}$

Dari serangkaian penjelasan sekilas profil pesantren tersebut, karena mencermati potensi pondok pesantren dalam rangka ikut mencerdaskan bangsa tidak diragukan lagi, pemerintah mempunyai kebijakan memberi bantuan. Akan tetapi pemberian bantuan ini sebatas pada pemberian bantuan dengan jargon-jargon program pemberdayaan pondok pesantren. Program pemberdayaan ini menyangkut pengembangan dan pemberian bekal keterampilan kerja pada santri pondok pesantren dan pengembangan lembaga pondok pesantren secara operasional dan lain sebagainya.

Walaupun demikian, keberadaan pondok pesantren tetap menjadi pendidikan jalur luar sekolah. Hal ini membawa konsekuensi out put pondok pesantren tidak diakui keberadaannya dengan lembaga pendidikan jalur sekolah. Begitu pula pemerintah masih menganggap proses belajar mengajar di pondok pesantren tidak memenuhi standar yang ditetapkan oleh pemerintah karena sistem pendidikan pondok pesantren lebih didominasi oleh muatan-muatan agama, menggunakan kurikulum yang belum standar, memiliki struktur yang tidak seragam, dan menggunakan manajemen yang tidak dapat dikontrol oleh pemerintah. Perlu disadari bahwa hal ini sebagai akibat pemerintah menganut sistem pendidikan Belanda yang dinilai lebih modern dan mempunyai sistem yang standar.

\footnotetext{
${ }^{20}$ Lihat Kepmenag No. 225 tahun 1992 tanggal 01-10-1992 tentang Subsidi Lembaga Keagamaan, Ponpok Pesantren dan Madrasah Swasta.

${ }^{21}$ Lihat Keputusan Ditjen Binbaga Agama Islam No. 80/E/1992 tanggal 30-9-1992 tentang Penetapan Pondok Pesantren Yang Mendapat Bantuan Untuk Tahun Anggaran 1992/1993. Keputusan itu dimuat dalam Himpunan Peraturan Perundang-Undangan Ditjen Binbaga Islam Tahun 1991\&1992 (Jakarta; Direktorat Jenderal Bimbingan Kelembagaan Agama Islam, 1993/1994).
} 
Tentunya hal ini membawa dampak pada kemarjinalan posisi pesantren dalam sistem pendidikan nasional. Lebih jelasnya, nampaknya pemerintah menerapkan standar ganda. Satu sisi pesantren masih dianggap pemerintah sebagai lembaga yang harus dibina dan dikembangkan karena mempunyai peran yang cukup strategis untuk ikut memobolisasi masyarakat guna mendukung stabilnya pembangunan ekonomi, namun di sisi lain keberadaan pondok pesantren masih ditempatkan jauh dari sistem pendidikan nasional. Karena bagaimanpun juga sistem pendidikan pondok pesantren dianggap tidak mempunyai standar yang baku.

Akan tetapi, walaupun pemerintah masih belum mengakui keberadaan pondok pesantren dalam sistem pendidikan nasional, perlu kiranya kita menghargai peran pemerintah untuk memberikan pencerahan terhadap pendidikan pondok pesantren. Berbagai upaya telah dilakukan pemerintah dalam mengembangkan potensi santri secara aplikatif. Pembinaan ini telah dilakukan pemerintah sejak Pelita II hingga sekarang. Program pembinaan Pondok Pesantren secara umum dapat dikelompokkan menjadi tiga bagian, yakni pertama, pengkaderan ulama dan pngembangan keilmuan. Kedua, mensukseskan wajib belajar pendidikan dasar sembilan tahun. Ketiga, pengembangan masyarakat. ${ }^{22}$

Secara rinci masing-masing program dapat dikemukakan sebagai berikut; pertama, pengkaderan ulama dan pengembangan keilmuan yang ditempuh dengan mengadakan; 1) Penataan tenaga pembina pondok pesantren tingkat nasional. 2) Penataan tenaga perpustakaan pondok pesantren. 3) Konsultasi pimpinan pondok pesantren seluruh Indonesia. 4) Bantuan kitab-kitab perpustakaan dan perpustakaan umum. 5) Bantuan biaya operasional MAK di pondok pesantren. 6) Pengembangan Ma'had Aly (pesantren tinggi). 7) Halaqah (kajian keilmuan) antara pimpinan pondok pesantren.

Kedua, mensukseskan wajib belajar 9 tahun yang ditempuh dengan; 1) Bantuan alat peraga IPA-Mts bagi pondok pesantren yang menyelenggarakan Mts. 2) Bantuan alat-alat

\footnotetext{
${ }^{22}$ Departemen Agama RI, Pondok Pesantren..., h. 12.
} 
olah raga dan alat kesenian. 3) bantuan keuangan untuk rehabilitasi lokal santri (asrama). 4) Koordinasi kerja paket A dan B antara instansi terkait dan pondok pesantren. 4) menyelenggarakan Mts terbuka di pondok pesantren salafiyah.

Ketiga, pengembangan masyarakat yang dilakukan dengan cara memberikan; 1) Bantuan alat-alat ketrampilan kepada pondok pesantren. 2) Penataran unit usaha dan koperasi pondok pesantren. 3) Bantuan gedung keuangan untuk Workshop(bengkel kerja). 4) Pelatihan instruktur keterampilan, latihan kerja santri atau latihan kerja mandiri. 5) Pelatihan pengembang agribisnis di pondok pesantren 6) Pelatihan pers dan jurnalistik santri pondok pesantren (kerjasama dengan Depnaker). 7) Pelatihan pers dan jurnalistik santri pondok pesantren (kerjasama Depnaker). 8) Bantuan keuangan untuk pengembangan sanitasi di pondok pesantren. 8) Bantuan operasional pondok pesantren. 9) Pemasyarakatan Bank Perkereditan Rakyat Syari'ah (BPRS), kerjasama Departemen Keuangan, Koperasi \& PPK dan Bank Indonesia. 10) Penyelenggaraan Wartel Koperasi/ Unit usaha pondok pesantren kerjasama dengan PT. Telkom. 11) Pelatihan kader kesehatan bagi santri pondok pesantren.

Persoalan lain yang perlu diamati adalah bahwa ternyata dari data yang terkumpul semua pondok pesantren adalah swata.beberapa dimiliki oleh sebuah yayasan, beberapa lagi oleh organisasi atau perorangan. Setiap pesantren memiliki ciri khas dan spesialisasi khusus, biasanya tergantung keahlian masingmasing kyai pengasuh. Walaupun tentunya terdapat juga pesantren yang sudah sangat modern dan tidak lagi tergantung pada kyai, tapi pada sistem yang telah berhasil diciptakan oleh para pendirinya. Sebagai contoh pondok pesantren Krapyak Yogyakarta lebih terkenal pada kajian qur'annya, pesantren Raudlatut Thalibin Rembang lebih terkenal ilmu alat (nahwu dan sharf), Pesantren Sarang Lasem lebih terkenal kajian kitab kuningnya dan lain sebagainya. Tentunya masing-masing pesantren tidak lepas dari beberapa kajian keagamaan Islam yang biasanya sangat populer seputar; tauhid, fiqh, akhlak, nahw/sharf, tafsir, hadits, ushul fiqh, tahfidz, hisab, 'arudl, filsafat dan lain sebagainya. 


\section{Penutup}

Berdiskusi masalah pendidikan di Indonesia, lembaga pendidikan pesantren memang merupakan lembaga yang unik dan khas Njawani (baca; Indonesia). Oleh karena itu, pesantren harus mendapat tempat yang layak dalam bingkai pendidikan nasional. Sangat disayangkan selama ini pemerintah masih merasa malu-malu untuk mengakui pendidikan pesantren sebagai pendidikan formal, berbagai ragam argumen dijadikan alasan untuk menolak dan meminggirkan pesantren dalam kancah pendidikan formal. Tentunya, hal ini sangat memprihatinkan di tengah kondisi bangsa yang morat-marit diperlukan lembaga pendidikan yang mampu membentengi moral bangsa. Pesantren sebagai jawaban yang paling ideal mengembangkan kualitas sumber manusia Indonesia.

\section{DAFTAR PUSTAKA}

A. Gaffar Karim, Metamorfosis NU dan Politisasi Islam Indonesia, Yogyakarta; LKiS, 1995.

Andree Feillard, NU Vis-à-vis Negara: Pencarian Isi, Bentuk dan Makna, penerj. Lesmana, Yogyakarta; LKiS, 1999.

Azyumardi Azra,"Pesantren: Kontinuitas dan Perubahan," dalam Nurcholish Madjid, Bilik-Bilik Pesantren....

Dawam Rahardjo, "Kyai dalam Perubahan Sosial," dalam Pesantren, No. 4/ Vol. II/1985.

Depag RI, Pondok Pesantren, Jakarta; Depag, 2001.

Erfan Maryono,"Aktualisasi Peran Kemasyarakatan Pesantren: Refleksi Pengalaman LPSM," dalam Pesantren No. 3/Vol. V/1998.

Hiroko Horikoshi, Kyai Dan Perubahan Sosial, Jakarta; P3M, 1987.

Jajat Burhanuddin, "Ulama dan Politik Pembentukan Umat: Sekilas Pengalaman Sejarah Indonesia," dalam Jajat Burhanuddin dan Ahmad Baedlowi, Transformasi Otoritas Keagamaan: Pengalaman Islam Indonesia, Jakarta; Gramedia, 2003. 
Pesantren Dalam Bingkai, oleh: Ahmad Ali Riyadi

Kepmenag No. 225 tahun 1992 tanggal 01-10-1992 tentang Subsidi Lembaga Keagamaan, Pondok Pesantren dan Madrasah Swasta.

Kuntowijoyo, Paradigma Islam: Interpretasi Untuk Aksi, Bandung; Mizan, 1993.

Kuntowijoyo, Paradigma Islam..., hal. 258. Bandingkan dengan Arief Mudatsir, "Kajen Desa Pesantren," dalam Dawam Rahardjo, Persantren dan Pembaharuan...

Mochtar Mas'ud, Ekonomi dan Struktur Politik Orde Baru 1966-1971, Jakarta; LP3ES, 1989.

Muhammad Asfar,"Pergeseran Otoritas Kepemimpinan Politik Kiai," dalam Prisma 5, Mei 1995.

Peraturan Pemerintah Republik Indonesia Nomor 73 tahun 1991 tentang Pendidikan Luar Sekolah", dalam Himpunan Peraturan Perundang-Undangan Tentang Pendidikan Nasional (Perguruan Agama Islam), Depag RI; Ditjen Binbaga Islam, 1998.

Purwo Santoso, "Kiprah Pesantren dalam Transformasi: Catatan dari Maslakul Huda," dalam Pesantren No. 3/Vol.V/1988.

Sudirman Tebba, "Dilema Pesantren: Belenggu Politik dan Pembaruan Sosial," dalam Dawam Rahardjo (edt.), Pergulatan Dunia Pesantren: Membangun Dari Bawah, Jakarta; P3M, 1985.

Tempo, 21 September 1991 dan 30 Mei 1992; Surabaya Post, 20-29 Mei 1992.

Wahid Zaini, Dunia Pemikiran Kaum Santri, Yogyakarta; LPSM NU DIY, 1995.

Yaqub, Pondok Pesantren dan Pembangunan Masyarakat Desa, Bandung; Angkasa, 1983. 